\title{
Rancang Bangun dan Studi Eksperimental Pengaruh Perbedaan Jarak Pitch dan Kemiringan Poros terhadap Kinerja Mekanik Model Turbin Ulir 2 Blade Pada Aliran Head Rendah
}

\author{
Yul Hizhar ${ }^{1}$, Bambang Yulistianto ${ }^{2}$, Suryo Darmo $^{3}$ \\ ${ }^{1}$ Jurusan Teknik Mesin, Fakultas Teknik, Universitas Andalas, Padang, Indonesia \\ ${ }^{2}$ Jurusan Teknik Sipil dan Hidrolika, Fakultas Teknik, Universitas Gadjah Mada, Yogyakarta, Indonesia \\ ${ }^{3}$ Jurusan Teknik Mesin, Fakultas Teknik, Universitas Gadjah Mada, Yogyakarta, Indonesia
}

INFORMASI ARTIKEL

Sejarah Artikel:

Diterima Redaksi: 02 Februari 2017

Revisi Akhir: 01 Maret 2017

Diterbitkan Online: 01 April 2017

KATA KUNCI

Screw turbine model

Pitch distance

Shaft slope

Rotation speed

Turbine power

Turbine efficiency

KORESPONDENSI

E-mail: yul_hizhar@ft.unand.ac.id

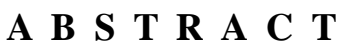

Screw turbine uses low head and high flow rate of water to generate rotation speed. Screw turbine has many advantages such as simple in construction and installation, low cost in operating and maintenance, and fish-friendly. The influencing parameters to mechanics performance of screw turbine are pitch distance and the shaft slope. The purposes of this research are to design 2-blades screw turbine model and to test the influence of pitch distance variation and shaft slope to mechanics performance in laboratory. This research used experimental method which each of screw turbine model with pitch of 2 Ro, 1.6Ro, and $1.2 \mathrm{Ro}$ were tested in variation of shaft slope of $25^{\circ}, 30^{\circ}, 35^{\circ}, 40^{\circ}$, and $45^{\circ}$. The water flow rate was $0.00728 \mathrm{~m}^{3} / \mathrm{s}$. The data was acquisitioned at Hydraulics Laboratory Civil Diploma Universitas Gadjah Mada. The result of testing without load showed that screw turbine model pitch of $2 \mathrm{Ro}$ had the higher rotation speed than pitch of 1.6Ro and 1.2Ro which the highest rotation speed was $255 \mathrm{rpm}$ at shaft slope of $35^{\circ}$. The result of testing with load showed that each turbine produced the highest rotation speed and output power at the shaft slope of $35^{\circ}$, meanwhile the highest efficiency was produced at the shaft slope of $25^{\circ}$. The result of research showed that generally screw turbine model pitch of 2Ro produced the higher mechanics performance (output power and efficiency) than pitch of $1.6 \mathrm{Ro}$ and $1.2 \mathrm{Ro}$. At the shaft slope of $25^{\circ}$, pitch $2 \mathrm{Ro}$ produced power $15.89 \mathrm{~W}$ and efficiency $73.08 \%$ (the highest), meanwhile at the shaft slope of $35^{\circ}$, pitch 2 Ro produced power $18.51 \mathrm{~W}$ (the highest) and efficiency $66.16 \%$. These efficiencies result difference were caused by the influence of the difference of hydropower (input power) at the variations of the shaft slopes.
\end{abstract}

\section{PENDAhuluan}

Indonesia adalah negara yang cukup kaya dengan potensi energi terbarukan seperti energi mini/ mikrohidro, energi biomassa, energi surya, energi angin, energi panas bumi, energi laut, dan energi nuklir. Khusus untuk mikrohidro, pengembangannya biasanya memanfaatkan potensi aliran air dengan head (ketinggian) dan debit tertentu yang dikonversi menjadi energi listrik melalui turbin dan generator. Pada kenyataannnya, di Indonesia, rata-rata menunjukkan bahwa potensi sumber daya airnya memiliki debit besar dan head 
yang rendah. Jadi, pengembangan turbin head rendah (low head) atau head sangat rendah (ultra low head) sangat cocok dikembangkan di Indonesia.

Maka dari permasalahan di atas, penulis tertarik untuk mengembangkan jenis turbin yang dapat beroperasi optimal pada head rendah debit tinggi. Di dalam penelitian ini, penulis mengembangkan penelitian tentang turbin ulir. Turbin ini beroperasi dengan putaran rendah dan masih tergolong baru dikembangkan di Indonesia, namun turbin ini memiliki beberapa keunggulan di antara jenis turbin head rendah yang lain tidak memerlukan sistem kontrol khusus karena penggunaan unit peralatan dan generator yang standar, mudah dalam konstruksi, mudah dalam instalasi dan perawatan, ramah lingkungan dan fish-friendly, efisiensi turbin yang tinggi untuk kondisi operasi head rendah dan debit tinggi.

Kinerja sebuah turbin ulir dipengaruhi oleh parameter-parameter yang terkait dalam perancangan turbin ulir itu sendiri. Salah satu parameter penting dalam perancangan turbin ulir adalah pitch atau jarak periode dari sebuah sudu (blade). Aspek lain dalam pertimbangan rancangan turbin ulir adalah pemasangan turbin atau kemiringan poros. Berdasarkan uraian tersebut diatas, penulis tertarik mengembangkan penelitian tentang turbin ulir yang bertujuan mengetahui pengaruh perbedaan jarak pitch dan kemiringan poros terhadap kinerja mekanik turbin ulir 2 blade serta sebagai referensi dalam pengembangan turbin ulir sebagai penggerak mula (prime mover) dalam pembangkit skala kecil (mikrohidro).

\section{TINJAUAN PUSTAKA}

Rorres menyatakan bahwa geometri dari sebuah ulir Archimedes (Archimedes screw) ditentukan oleh beberapa parameter eksternal yaitu jari-jari terluar, panjang ulir, dan kemiringan. Parameter-parameter lain yang mempengaruhi adalah parameter internal seperti jari-jari dalam, jumlah blade, dan pitch blade. Parameter-parameter eksternal tersebut biasanya ditentukan oleh lokasi penempatan ulir Archimedes dan seberapa banyak air yang akan diangkat. Sementara parameter-parameter internal adalah bebas ditentukan sendiri untuk mengoptimalkan performansi atau kinerja dari ulir [1].

Menurut Fraengkel, Archimedean screw pump adalah pompa tertua yang pernah ada semenjak orang menaruh perhatian terhadap pemindahan cairan. Namun demikian jenis pompa ini sampai sekarang masih banyak digunakan karena beberapa kelebihannya. Pompa ini dapat bekerja secara optimum pada sudut instalasi $30^{\circ}$ sampai $40^{\circ}$ [2].

Menurut Ritz-Atro Pumpwerksbau $\mathrm{GmbH}$, prinsip kerja turbin ulir Archimedean hydrodynamic adalah pembalikan dari pompa Archimedean dimana turbin ini memanfaatkan energi aliran air menjadi energi mekanik. Kemiringan turbin ulir berkisar dari $22^{\circ}$ $30^{\circ}[3]$.

Menurut Paish, ulir Archimedes telah digunakan sebagai pompa selama berabad-abad, namun baru saat ini fungsinya dibalikkan sebagai turbin. Akan tetapi, turbin ulir masih merupakan mesin kecepatan rendah yang membutuhkan sebuah gearbox bertingkat untuk menggerakkan sebuah generator [4].

\section{METODOLOGI}

Peralatan utama yang digunakan pada penelitian ini yaitu:

a. Model turbin ulir yang akan diuji.

b. Tachometer untuk mengukur kecepatan putaran turbin.

c. Ember ukur kapasitas 60 liter dan stopwatch untuk mengukur debit.

d. Busur untuk mengukur kemiringan poros turbin.

e. Mistar baja untuk mengukur ketinggian muka air.

f. Neraca pegas dan neraca digital untuk mengukur beban pengereman dalam pengukuran torsi.

Penelitian ini bersifat ekperimen dan variabel yang ada terbagi atas: 
a. Variabel bebas (independent variable), terdiri dari pitch (1) dan kemiringan poros turbin $(\theta)$.

b. Variabel terikat (dependent variable), terdiri dari kecepatan putar turbin $(n)$, torsi $(T)$, daya air $(P f)$, daya turbin $(P t)$, dan efisiensi turbin $(\eta)$.

c. Variabel kontrol (control variable), terdiri dari debit $(Q)$, kecepatan aliran air $(v)$, jari-jari dalam $(R i)$, jari-jari luar $(R o)$, sudut ulir dalam $(\beta)$, sudut ulir luar $(\alpha)$, panjang turbin $(L)$, tinggi sudu $(t)$, jumlah lingkaran sudu $(n b)$, dan jumlah sudu $(N)$.

Penelitian ini dilaksanakan di Laboratorium Hidrolika D3 Sipil Universitas Gadjah Mada. Gambar 1 menunjukkan rangkaian alat pengujian model turbin ulir 2 sudu.

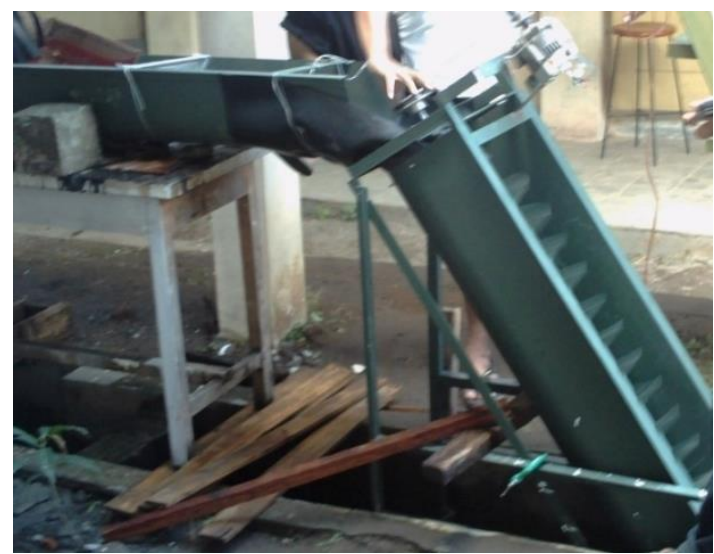

(a)

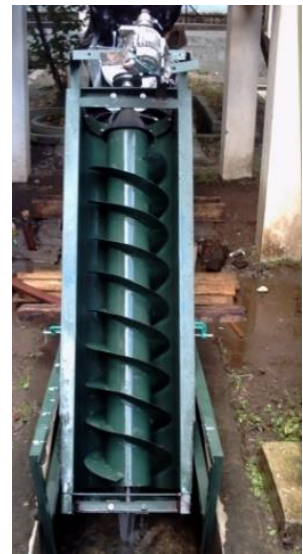

(b)

Gambar 2. Rangkaian alat pengujian model turbin ulir 2 sudu, (a) tampak samping, (b) tampak depan

Model turbin ulir yang berbeda pitch ditunjukkan pada Gambar 2.

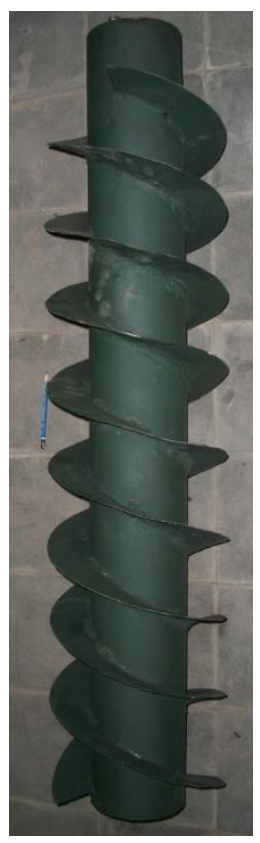

(a)

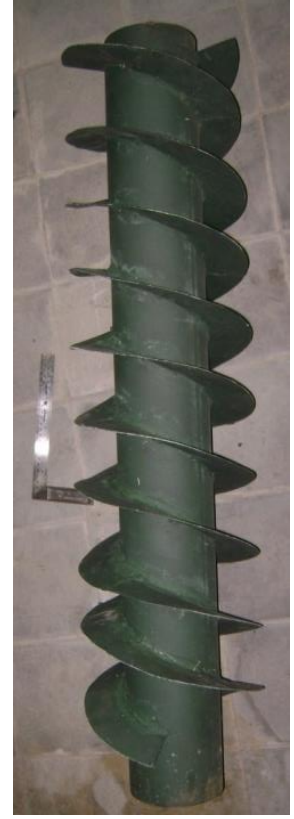

(b)

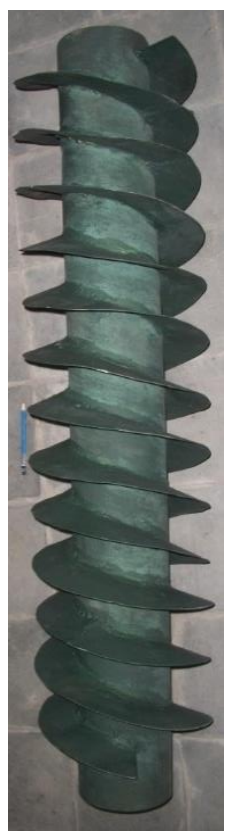

(c)

Gambar 2. Tiga macam model turbin ulir, (a) ulir pitch 2Ro, (b) ulir pitch 1,6Ro, (c) ulir pitch 1,2 Ro 


\section{HASIL DAN PEMBAHASAN}

\subsection{Pengujian Tanpa Beban}

Pengujian tanpa beban bertujuan untuk melihat pengaruh variasi tiga pitch dan kemiringan poros model turbin ulir terhadap kecepatan putaran turbin pada saat turbin belum dibebani. Variasi kemiringan poros turbin adalah $25^{\circ}, 30^{\circ}, 35^{\circ}, 40^{\circ}$, dan $45^{\circ}$. Debit aliran yang digunakan adalah konstan yaitu $0,00728 \mathrm{~m}^{3} / \mathrm{s}$. Hubungan antara kemiringan poros dan kecepatan putaran turbin tanpa beban dapat dilihat pada Gambar 3.

Perubahan kecepatan putaran turbin ini terjadi karena pengaruh daya aliran yang menumbuk blade. Pada variasi kemiringan $25^{\circ}$ hingga $35^{\circ}$, pola aliran masih stabil dan tidak terjadi loncatan ketika menumbuk lingkaran ulir blade sehingga gaya aliran $F a$ bekerja efisien untuk menghasilkan gaya tangensial dan putaran turbin. Namun, pada variasi kemiringan poros $40^{\circ}$ dan $45^{\circ}$, terlihat adanya perubahan bentuk aliran di mana aliran air cenderung meloncat dari ujung flume dan tidak tepat lagi menumbuk lingkaran ulir pertama blade. Aliran air cenderung menumbuk bagian tengah rotor atau poros dalam $(D i)$ sebelum menumbuk lingkaran ulir pertama dari blade turbin. Gaya aliran air $F a$ yang berkurang pada blade ini menyebakan penurunan gaya tangensial, sehingga kecepatan putaran turbin juga berkurang.

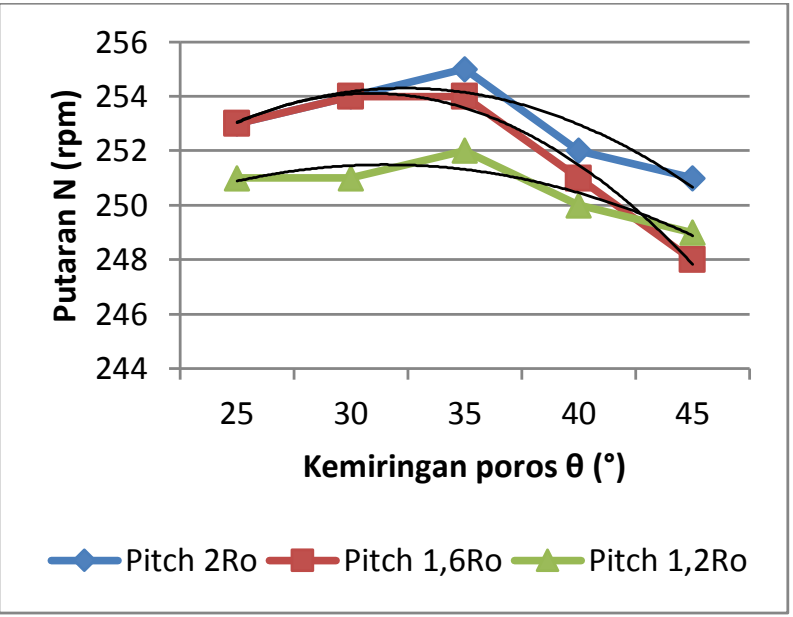

Gambar 3. Grafik hubungan antara putaran turbin dan kemiringan poros pada pengujian tanpa beban
Pada pengujian tanpa beban ini, meskipun selisih kecepatan putaran yang dihasilkan antara tiap model turbin ulir tidak begitu besar, namum secara umum model turbin ulir pitch 2Ro menghasilkan kecepatan putaran yang lebih tinggi dibandingkan model turbin ulir pitch 1,6Ro dan 1,2Ro. Kecepatan putaran tertinggi dihasilkan oleh masing-masing model turbin ulir pada kemiringan poros $35^{\circ}$, di mana model turbin ulir pitch 2Ro menghasilkan 255 rpm, model turbin ulir pitch 1,6Ro menghasilkan $254 \mathrm{rpm}$, dan model turbin ulir pitch 1,2Ro menghasilkan $252 \mathrm{rpm}$.

\subsection{Perbandingan Kinerja Mekanik Model Turbin Ulir Antara Hasil Pengujian dan Hasil Teoritis}

Torsi yang dihasilkan oleh setiap model turbin ulir dalam penelitian ini dapat di tentukan secara teoritis. Parameter-parameter yang harus diketahui untuk mencari torsi teoritis yang dihasilkan oleh sebuah turbin ulir adalah gaya tangensial $F t$ yang dihasilkan oleh sebuah lingkaran ulir, jari-jari momen puntir $r$, dan jumlah total lingkaran ulir $n b$.

Perhitungan untuk mencari gaya tangensial yang dihasilkan oleh sebuah turbin ulir dapat ditentukan secara teoritis dengan menggunakan pendekatan perhitungan pada ulir-ulir daya (power screw). Gaya-gaya yang bekerja pada sebuah lingkaran blade ulir akibat gaya aksial aliran fluida air $F a$ ditunjukkan dalam Gambar 4.

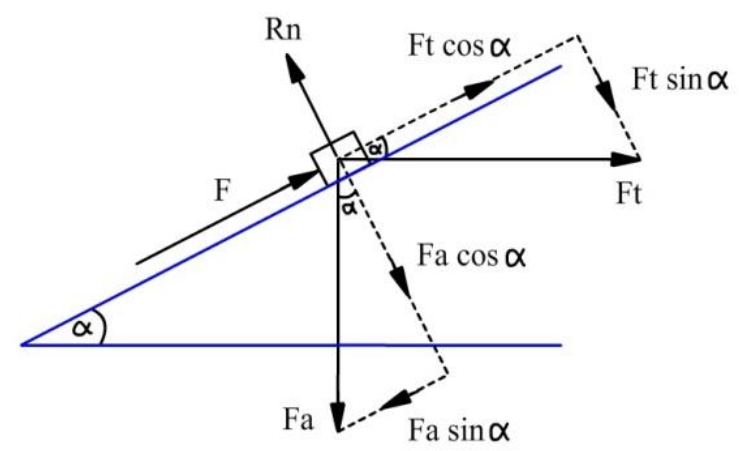

Gambar 4. Gaya-gaya yang bekerja pada sebuah lingkaran blade turbin ulir 
Gambar 4 menunjukkan fluida air dengan laju aliran tertentu menumbuk sebuah lingkaran blade turbin ulir secara aksial dan menghasilkan gaya aksial $\mathrm{Fa}$ yang arahnya sejajar sumbu poros. Adanya gaya aksial $F a$ menimbulkan reaksi dari turbin berupa gaya tangensial $F t$ yang arahnya tegak lurus sumbu poros. Sementara, gaya gesekan $F$ yang timbul akibat kontak antara fluida air dan blade ulir akan mengurangi gaya aksial $F a$. Harga gaya gesekan $F$ merupakan perkalian dari koefisien gesekan yang terjadi dengan gaya normal $(F=\mu$. $R n)$.

\subsubsection{Perbandingan Torsi Hasil Pengujian} Terhadap Torsi Secara Teoritis

Grafik perbandingan antara torsi hasil pengujian dan torsi secara teoritis pada variasi kemiringan poros dapat dilihat pada Gambar 5 - 7.

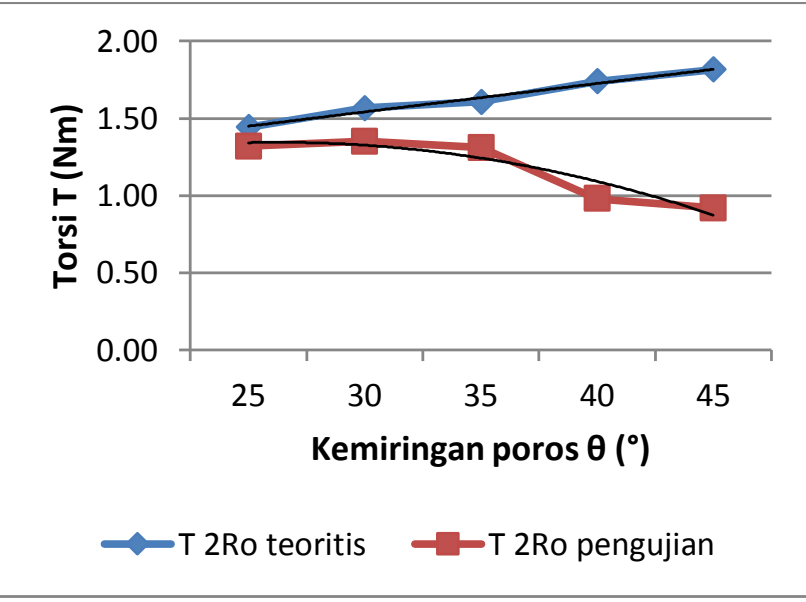

Gambar 5. Perbandingan torsi teoritis terhadap torsi hasil pengujian pitch $2 \mathrm{Ro}$

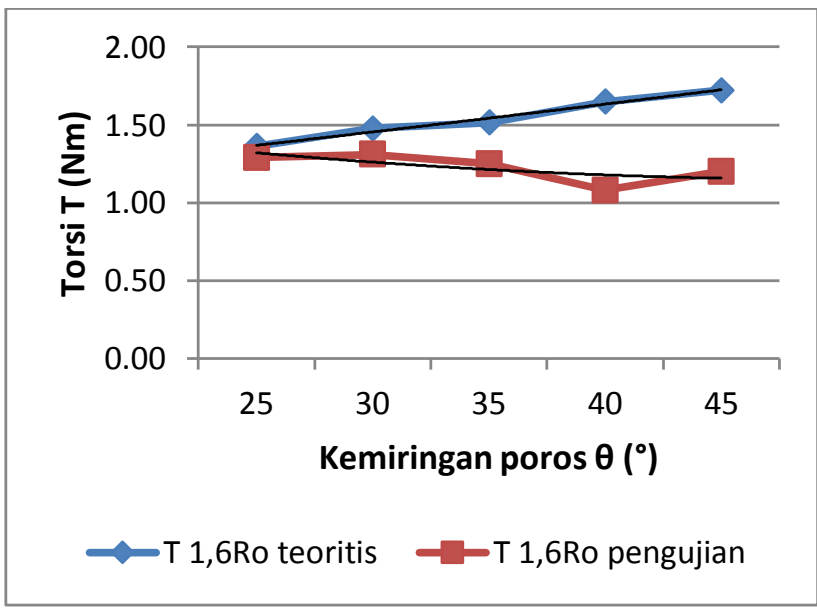

Gambar 6. Perbandingan torsi teoritis terhadap torsi hasil pengujian pitch 1,6Ro

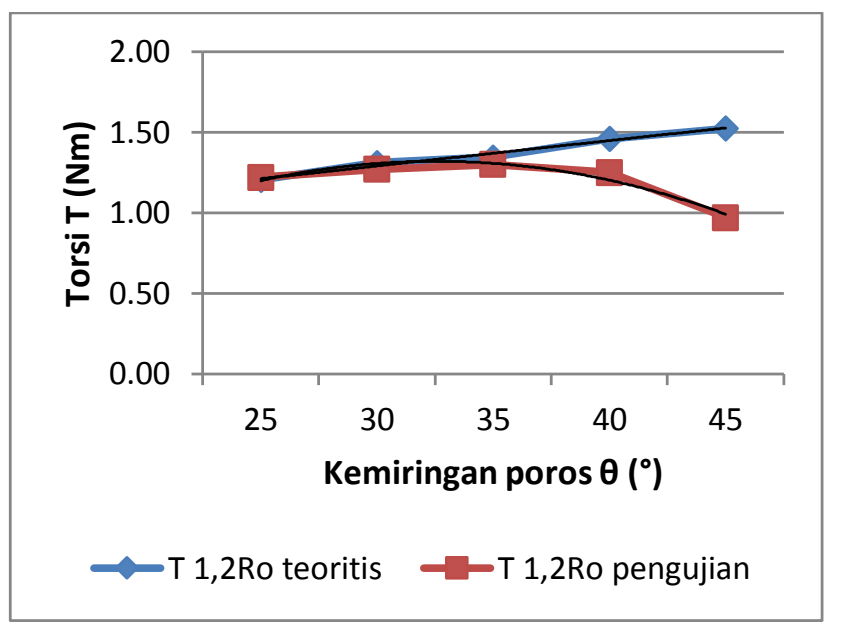

Gambar 7. Perbandingan torsi teoritis terhadap torsi hasil pengujian pitch 1,6Ro

Gambar 5 - 7 menunjukkan perbandingan torsi teoritis terhadap torsi hasil pengujian masingmasing pitch model turbin ulir. Data torsi teoritis masing-masing pitch ulir ditentukan dengan menggunakan persamaan-persamaan ulir daya (power screw), sementara data turbin hasil pengujian diperoleh dengan menggunakan pengukuran langsung dengan menggunakan metode pengereman (pronny brake). Pada grafik terlihat torsi teoritis masing-masing pitch ulir cenderung naik pada setiap kenaikan sudut poros, sedangkan torsi hasil pengujian menunjukkan kecenderungan menurun pada setiap kenaikan sudut poros.

Perbedaan nilai antara torsi teoritis dengan torsi hasil pengujian ini disebabkan oleh perbedaan cara pengambilan data. Data torsi teoritis masing-masing pitch ditentukan dengan menggunakan pendekatan rumus-rumus atau persamaan-persamaan ulir daya, di mana torsi (momen puntir) model turbin ulir dihasilkan oleh perkalian gaya tangensial turbin $F t$ dengan jari-jari $r$. Gaya tangensial turbin dihasilkan oleh gaya aliran fluida $F a$ yang secara aksial menumbuk setiap lingkaran ulir blade yang ada pada sebuah turbin ulir. Peningkatan gaya aliran fluida $F a$ pada setiap variasi kenaikan sudut poros menyebabkan peningkatan gaya tangensial dan torsi turbin secara teoritis.

Jadi pada data torsi secara teoritis, gaya aliran fluida $F a$ yang menumbuk setiap lingkaran ulir adalah seragam. Namun, pengujian di laboratorium menunjukkan pola aliran yang berbeda sehingga 
kecepatan aliran fluida yang menumbuk setiap lingkaran ulir tidak seragam. Hal inilah yang menyebabkan gaya tangensial dan torsi pengujian lebih rendah dari dari torsi teoritis. Kemungkinan lain penyebab torsi pengujian lebih rendah dari torsi teoritis adalah pengukuran selisih beban yang kurang akurat di laboratorium.

\subsubsection{Perbandingan Daya Hasil Pengujian Terhadap Daya Secara Teoritis}

Grafik perbandingan antara daya hasil pengujian dan daya secara teoritis pada variasi kemiringan poros dapat dilihat pada Gambar 8 - 10 .

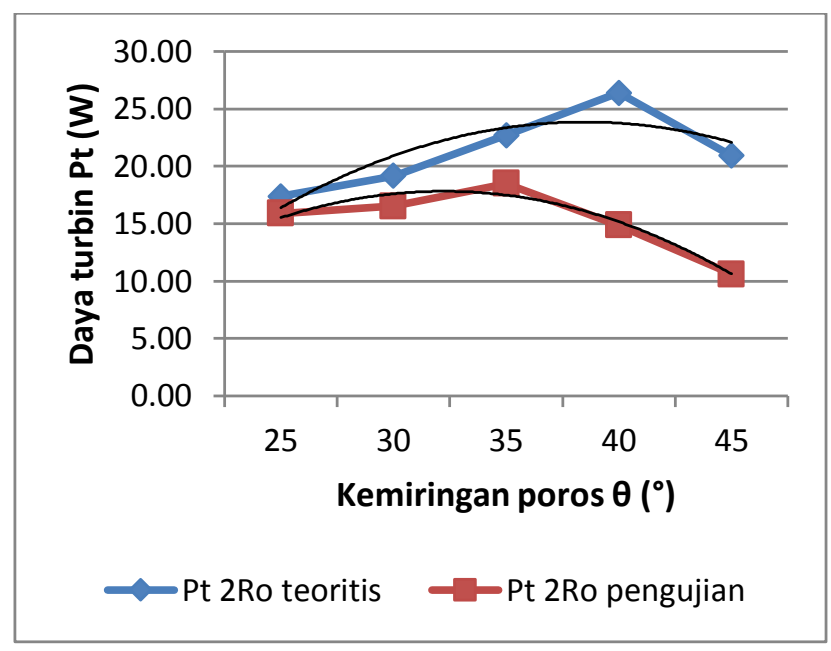

Gambar 8. Perbandingan daya teoritis terhadap daya hasil pengujian pitch 2Ro

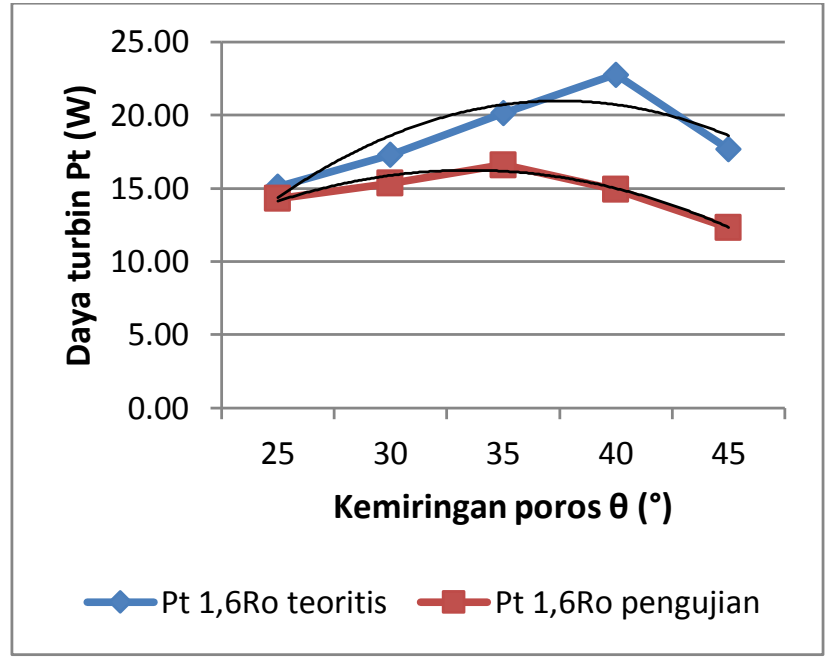

Gambar 9. Perbandingan daya teoritis terhadap daya hasil pengujian pitch 1,6Ro

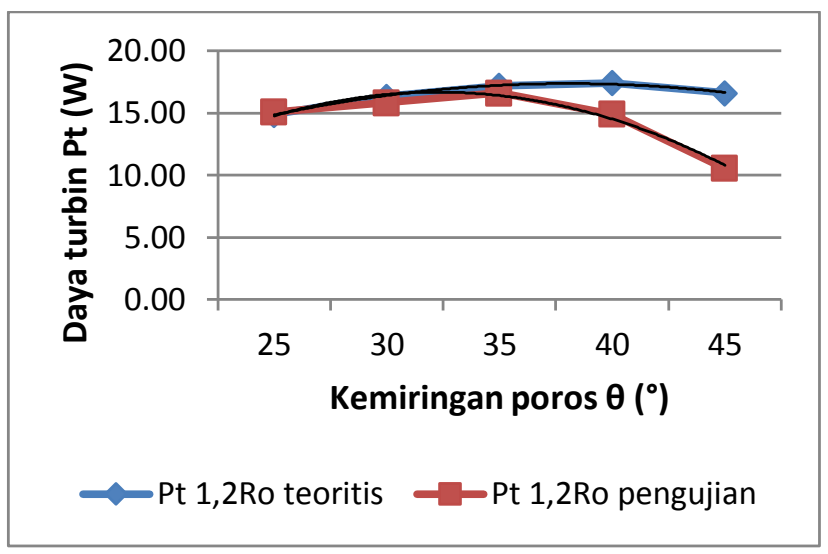

Gambar 10. Perbandingan daya teoritis terhadap daya hasil pengujian pitch 1,2Ro

Gambar 8 - 10 menunjukkan nilai daya turbin teoritis cenderung lebih besar daripada daya turbin hasil pengujian. Daya hasil pengujian tertinggi masing-masing pitch ulir dihasilkan pada kemiringan poros $35^{\circ}$, sedangkan daya teoritis tertinggi dihasilkan pada kemiringan poros $40^{\circ}$. Turbin pitch 2 Ro memberikan daya yang lebih baik daripada turbin pitch 1,6Ro dan 1,2Ro, di mana daya tertinggi pitch 2 Ro adalah $18,51 \mathrm{~W}$. Perbedaan nilai antara daya teoritis dengan daya hasil pengujian ini disebabkan perbedaan nilai torsi pada masing-masing pitch ulir.

\subsubsection{Perbandingan Efisiensi Hasil Pengujian Terhadap Efisiensi Secara Teoritis}

Grafik perbandingan antara efisiensi hasil pengujian dan efisiensi secara teoritis pada variasi kemiringan poros dapat dilihat pada Gambar $11-13$.

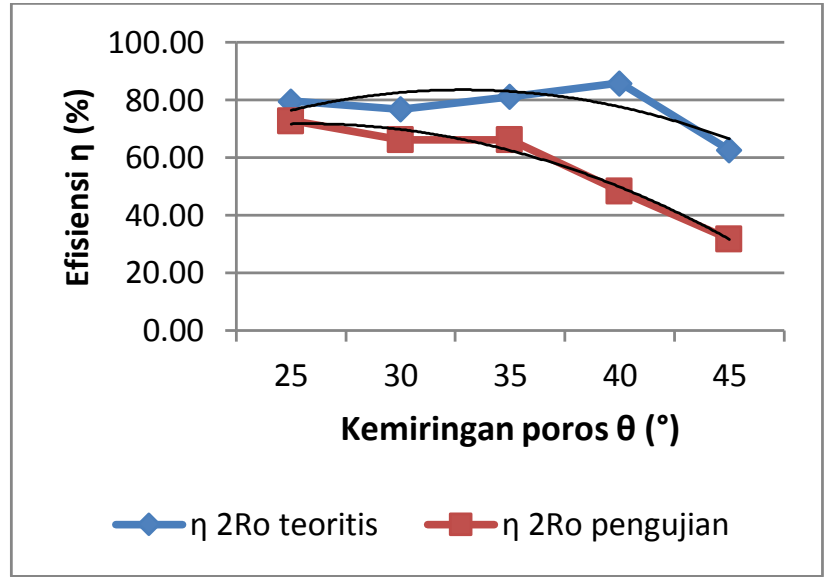

Gambar 11. Perbandingan efisiensi teoritis terhadap efisiensi pengujian pitch 2 Ro 


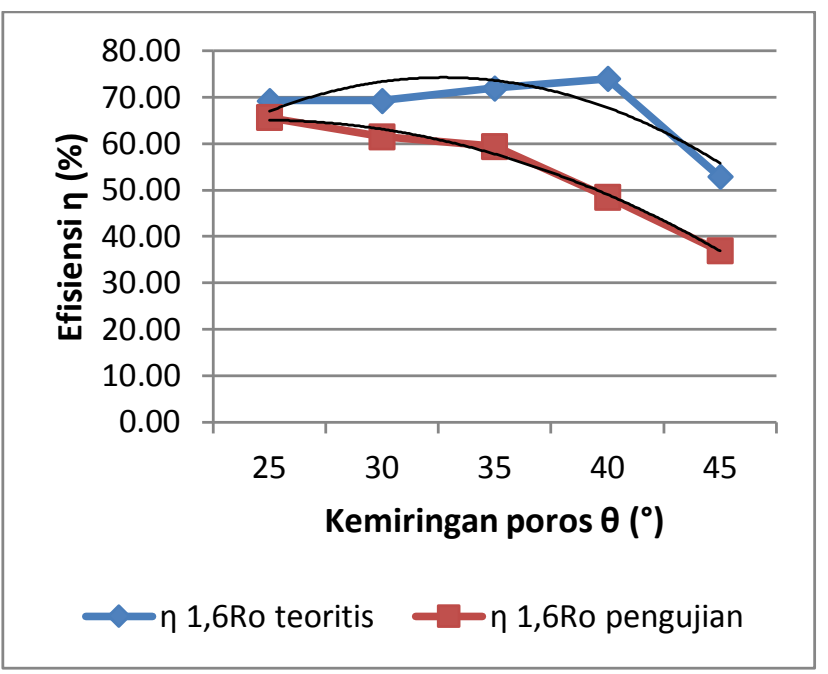

Gambar 12. Perbandingan efisiensi teoritis terhadap efisiensi pengujian pitch 1,6Ro

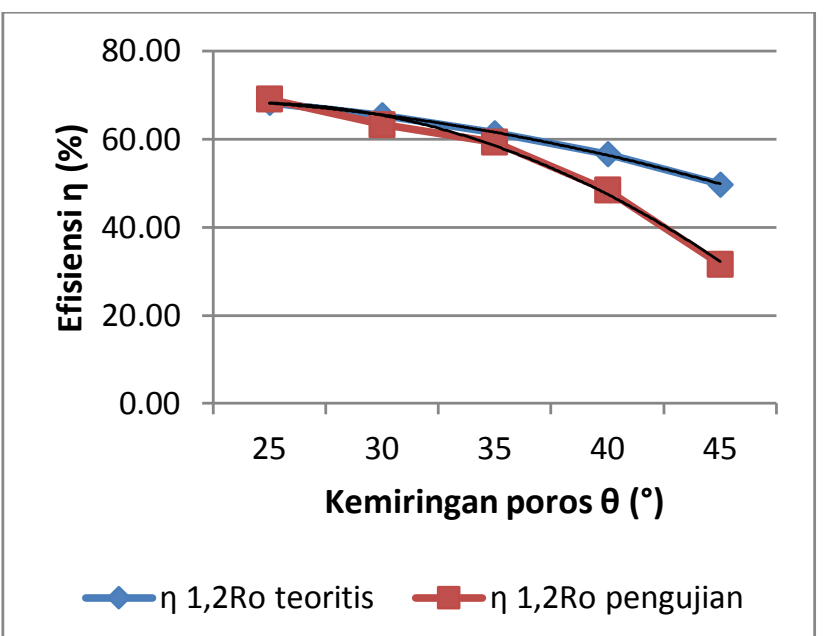

Gambar 12. Perbandingan efisiensi teoritis terhadap efisiensi pengujian pitch 1,6Ro

Gambar 11 - 13 menunjukkan bahwa pada kemiringan sudut poros $25^{\circ}$, ulir pitch 2 Ro menghasilkan daya sebesar 15,89 W dengan efisiensi $73,08 \%$ (tertinggi), sementara pada kemiringan sudut poros $35^{\circ}$, ulir pitch 2 Ro menghasilkan daya sebesar $18,51 \mathrm{~W}$ (tertinggi) dengan efisiensi $66,16 \%$. Perbedaan efisiensi ini diakibatkan oleh pengaruh perbedaan daya air (daya input) pada berbagai kemiringan sudut poros turbin .

\section{KESIMPULAN DAN SARAN}

\subsection{Kesimpulan}

Setelah melakukan pengujian dan analisa serta pembahasan data hasil pengujian maka diambil kesimpulan sebagai berikut: (1) Hasil rancangan model turbin ulir 2 blade berfungsi cukup baik pada pengujian di laboratorium dengan menggunakan debit aliran yang konstan sebesar sebesar 0,00728 $\mathrm{m}^{3} / \mathrm{s}$ dan variasi kemiringan sudut poros $25^{\circ}, 30^{\circ}$, $35^{\circ}, 40^{\circ}$, dan $45^{\circ}$; (2) Pada hasil pengujian tanpa beban, model turbin ulir dengan pitch 2Ro menghasilkan putaran lebih tinggi dibandingkan pitch 1,6Ro dan 1,2Ro; (3) Pada hasil pengujian berbeban, masing-masing model turbin ulir menghasilkan putaran dan daya tertinggi pada sudut kemiringan poros $35^{\circ}$, sementara efisiensi tertinggi dihasilkan pada kemiringan sudut poros $25^{\circ}$; (4) Pada kemiringan sudut poros $25^{\circ}$, ulir pitch 2Ro menghasilkan daya sebesar $15,89 \mathrm{~W}$ dengan efisiensi $73,08 \%$ (tertinggi), sementara pada kemiringan sudut poros $35^{\circ}$, ulir pitch 2Ro menghasilkan daya sebesar $18,51 \mathrm{~W}$ (tertinggi) dengan efisiensi $66,16 \%$.

\section{DAFTAR PUSTAKA}

[1] C. Rorres. "The Turn of the Screw: Optimal Design of An Archimedes Screw". Journal of Hydraulic Engineering, Vol. 126, No. 1, pp. 7280, 2000.

[2] P. L. Fraenkel. Water Lifting. Rome: Food and Agriculture Organization of the United Nations, 1986, pp. 86-89.

[3] Ritz-Atro Pumpwerksbau GmbH, "Hydrodynamic Screw", Max-Brod, Nuremberg, Germany, Report No. 08/2010, 2010.

[4] O. Paish. Small Scale Hydro Feasibility Study. Derwent Hydro, Derbyshire, UK, Report No. 10205, 2009.

[5] R. S. Khurmi dan J. K. Gupta. A Textbook of Machine Design. New Delhi: Eurasia Publishing House (PVT.) LTD., 2005, pp: 624676.

[6] B. R. Munson, D. F. Young, dan T. H. Okiishi. Mekanika Fluida Jilid 2, Edisi Keempat. Jakarta: Erlangga, 2005 pp: 111-266. 


\section{NOMENKLATUR}

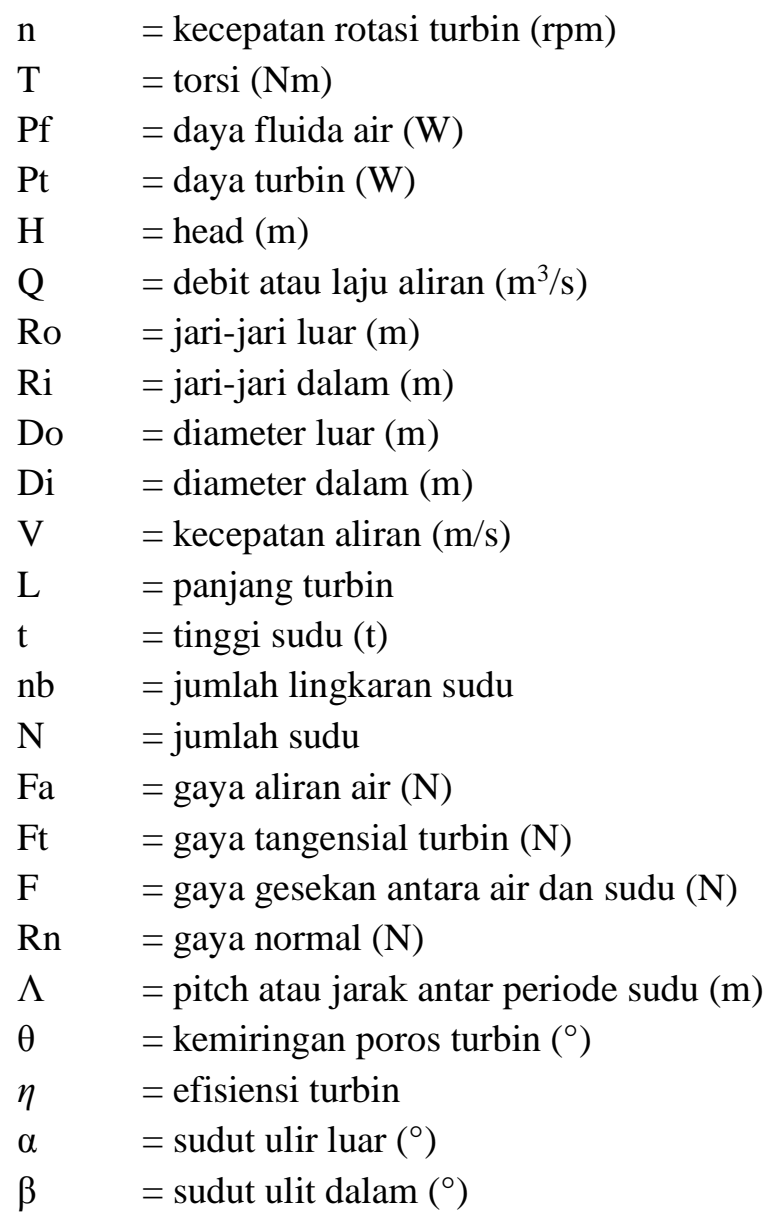

